\title{
Psychological and sexual effects of circumcision in adult males
}

\author{
Yasin Aydogmus, MD; Murat Semiz, MD; ${ }^{2}$ Okan Er, MD, Okan Bas, MD, Irfan Atay, MD,; \\ Muhammet Fatih Kilinc, $M D^{6}$
}

'Department of Urology, Etimesgut Military Hospital, Ankara, Turkey; ${ }^{2}$ Department of Psychiatry, Gulhane Military Medical Academy, Ankara, Turkey; ${ }^{3}$ Department of Psychiatry, Etimesgut Military Hospital, Ankara, Turkey; ${ }^{4}$ Department of Urology, Abdurrahman Yurtaslan Oncology Education and Research Hospital, Ankara, Turkey; ${ }^{5}$ Department of Urology, Health Centre of Airforce Military Academy, Istanbul, Turkey; ${ }^{6}$ Department of Urology, Ankara Training and Research Hospital, Ankara, Turkey

Cite as: Can Urol Assoc J 2016;10(5-6):E156-60. http://dx.doi.org/10.5489/cuaj.3364 Published online May 12, 2016.

\section{Abstract}

Introduction: Our aim was to investigate the psychological and sexual effects of circumcision in adult men, and analyze these changes following circumcision.

Methods: We included 37 adults who applied to our clinic for circumcision and who did not have any psychiatric or urologic disorders and age-matched 30 controls in our study. Body Cathexis Scale (BCS), Liebowitz Social Anxiety Scale (LSAS), and Premature Ejaculation Diagnostic Tool (PEDT) were applied to the study group twice, once before and once three months after circumcision, and only once in the control group. Also, intravaginal ejaculation latency time (IELT) was noted and premature ejaculation (PE) evaluation was done. Intra- and intergroup comparisons were performed.

Results: The two groups were similar with regard to demographic data. Comparison of preoperative BCS and LSAS scores with the scores of the control group showed significant differences $(p=0.003, p<0.001$, and $p<0.001$, respectively). However, postoperative scores were similar to the scores obtained in the control group $(p=0.768, p>0.05$, and $p>0.05$, respectively). Scores of all scales showed significant improvements postoperatively. Also, PEDT scores and IELT changes before and after circumcision were significant in the study group, but not when compared to the control group.

Conclusions: Our results indicated that social anxiety and anxiety levels decreased after circumcision in adult Turkish men, and their body gratification increased. We found that not being circumcised might negatively affect individuals in adulthood when it comes to body image and sexual satisfaction, however, both improve after circumcision.

\section{Introduction}

Circumcision has been performed since ancient times. Ancient depictions show that Australian Aborigines, Incas, Aztecs, Mayas, and ancient Egyptians performed circumcision. ${ }^{1}$ Circumcision is performed as a religious ritual in most Muslim and Jewish countries, and it is also frequently performed in Middle-Eastern countries, as well as in the U.S. ${ }^{2-4}$ World Health Organization reported that $30 \%$ of men worldwide and most Muslim men have been circumcised. ${ }^{5,6}$

Circumcision has historical, religious, and cultural importance, as well as psychological significance. It was reported that circumcision might have positive effects on mental health, may contribute father-son empathy, and activate masculine drives in children. ${ }^{7}$

Premature ejaculation $(\mathrm{PE})$ is one of the most common sexual disorders among the male population. It affects about $20-30 \%$ of all men. Up-to-date, lifelong PE has been defined by McMahon et al. ${ }^{8}$

We hypothesized that adult circumcision may change body image and social anxiety of the individual, and may affect ejaculation time and sexual satisfaction. Our hypothesis is based on the values of circumcision in the Turkish population.

\section{Methods}

A total of 37 men aged over 18 years admitted to our clinic for circumcision were included in the study, following an ethical committee approval. Individuals with a known psychotic disorder, mental retardation, systemic disorder, erectile dysfunction, congenital penile shape deformity, and previous penile surgery were excluded. The control group consisted of 30 age-matched healthy individuals who had circumcision performed in childhood.

\section{Procedure}

1. Before circumcision, a psychiatrist examined the individuals included in the study for psychotic disorders and mental retardation and an urologist evaluated them for ejaculation and circumcision.

2. The psychiatrist applied Body Cathexis Scale (BCS) and Liebowitz Social Anxiety Scale (LSAS); the urologist applied Premature Ejaculation Diagnostic Tool (PEDT) to the individuals and evaluated them for PE. The indi- 
viduals self-reported Intravaginal Ejaculation Latency Times (IELT) of $<1 \mathrm{~min}$ were approved as PE according to McMahon et al. ${ }^{8}$

3. Medical circumcision was performed under local anesthesia. The patients were discharged from the hospital, and called for a followup three months later.

4. Three months after the circumcision, evaluation described in item (2) was applied to the study group.

5. Evaluation described in item (2) was applied to the control group once.

Age, marital status, education level, and place of living of the participants were noted. They were asked, "Did you want to be circumcised before?" and "Do you think circumcision is necessary in your religion?"

The scales below were applied to the study group twice, once before and once three months after circumcision, under the supervision of the psychiatrist and urologist.

\section{Scales}

\section{Body Cathexis Scale (BCS)}

BCS is a five-point Likert scale described in 1953, and it consists of 40 questions. In the scale, 1 indicates "extremely satisfied" and 5 indicates "extremely dissatisfied." ${ }^{9}$ We used the validated Turkish version of the scale in our study. ${ }^{10}$

We analyzed the questions 30,35 , and 40 separately due to their emphasis on sexuality. Those were "my sexual potency," "my sexual activities," and "my sex organ," respectively.

\section{Liebowitz Social Anxiety Scale (LSAS)}

LSAS was prepared to measure healthy people and patients' fear and avoidance levels in case of social interaction and performance. It contains two subscales, anxiety and avoidance. Each section consists of 24 items. LSAS is a four- point Likert scale; 1 indicates "none/occasionally," and 4 indicates "severe." We used the validated Turkish version of LSAS in our study. ${ }^{11}$

Questions 4 and 24 in LSAS were analyzed separately due to the emphasis on sexual organs. Those were "trying to make someone's acquaintance for the purpose of a romantic/ sexual relationship" and "urinating in a public bathroom," respectively.

\section{Premature Ejaculation Diagnostic Tool (PEDT)}

PEDT was developed by Symonds for the systematical diagnosis of PE. ${ }^{12}$ We used the Turkish validated version of PEDT developed by Serefoglu..$^{13}$ PEDT consists of five items: control, frequency, minimal stimulation, distress, and interpersonal difficulty. Sensitivity and specificity analyses suggested a score of 8 indicates no PE, 9 and 10 indicate probable $\mathrm{PE}$, and 11 indicates $\mathrm{PE}$.

\section{Statistical analysis}

Pre- and post-circumcision data of the study group were compared with the control group data. In addition, pre- and post-circumcision data were compared. SPSS 16.0 package program was used for data analysis. Normality of distribution was analyzed with Kolmogorov-Smirnov and Shapiro-Wilk tests. Independent samples t-test was used for pairwise comparisons and paired samples t-test was used for comparison of pre- and post-circumcision data in the groups with a normal distribution. Pairwise comparisons of the groups that did not show normal distributions were done with Mann Whitney $U$ test, while Wilcoxon test was used to compare pre- and post- circumcision data in those groups. A p value $<0.05$ was considered statistically significant.

\section{Results}

The data on age, marital status, education level, and the religious need for circumcision of the groups are summarized in Table 1. The two groups had similar demographic characteristics.

Only the individuals in the study group were asked whether they wanted to be circumcised before. Thirty-four of the individuals replied to this question with "Yes," two replied "No," and one replied "It does not matter." We learned that the reason of the three individuals responding to this question as "No" or "It does not matter" was associated with religion. These three individuals were Christian and only wanted to be circumcised after they had changed their religion to Muslim. Pre- and post-circumcision body image and social anxiety were not found different in those individuals. Statistical analysis of the latter subjects could not be performed due to low sample size.

Table 2 shows the BCS, total scores of questions 30, 35, and 40; scores of anxiety and avoidance subscales of LSAS; and the total scores of questions 4 and 24 in anxiety and

\begin{tabular}{|c|c|c|c|c|}
\hline & & $\begin{array}{c}\text { Study } \\
n=37\end{array}$ & $\begin{array}{c}\text { Control } \\
n=30\end{array}$ & $p$ value \\
\hline Age & & $\begin{array}{l}22 \pm 1.8 \\
(20-27)\end{array}$ & $\begin{array}{l}23 \pm 2.3 \\
(20-28)\end{array}$ & 0.30 \\
\hline \multirow{2}{*}{ Martial status } & Married & 4 & 5 & \multirow{2}{*}{0.49} \\
\hline & Single & 33 & 25 & \\
\hline \multirow{3}{*}{$\begin{array}{l}\text { Education } \\
\text { (School level) }\end{array}$} & Primary & 3 & 4 & \multirow{3}{*}{0.88} \\
\hline & Seconday & 29 & 21 & \\
\hline & University & 5 & 5 & \\
\hline \multirow{2}{*}{ Living place } & Village & 10 & 8 & \multirow{2}{*}{0.97} \\
\hline & City & 27 & 22 & \\
\hline \multirow{2}{*}{$\begin{array}{l}\text { Is circumcision } \\
\text { a religious } \\
\text { requirement? }\end{array}$} & Yes & 34 & 30 & \multirow[b]{2}{*}{0.11} \\
\hline & No & 3 & 0 & \\
\hline
\end{tabular}


avoidance subscales. Pre-circumcision BCS and LSAS of the study and the control groups showed significant differences. However, post-circumcision scores and control group scores were similar. There were significant reductions between preand post-circumcision scores for both BCS and LSAS, and also in the mean scores of the items with a sexual content in BCS and LSAS.

PE was seen in $32 \%$ of the preoperative study group, $22 \%$ of the postoperative study group, and $23 \%$ of controls. There was no significant difference between pre- and postoperative study group and control group for PEDT scores, IELT, values and presence of PE. When pre-and postoperative values were compared, there was significant improvement of the PEDT scores, IELT values, and presence of PE (Tables 2, 3).

\begin{tabular}{|c|c|c|c|c|c|}
\hline & & $\begin{array}{l}\text { Study } \\
\mathrm{n}=37\end{array}$ & $\begin{array}{c}p \\
\text { value }^{1}\end{array}$ & $\begin{array}{c}\text { Control } \\
n=30\end{array}$ & $\begin{array}{c}p \\
\text { value }^{2}\end{array}$ \\
\hline \multirow{2}{*}{ BCS } & $\begin{array}{c}\text { Before } \\
\text { circumcision }\end{array}$ & $\begin{array}{c}80.9 \pm 12.1 \\
(51-102)\end{array}$ & \multirow{2}{*}{$<0.01$} & \multirow{2}{*}{$\begin{array}{c}72.4 \pm 10 \\
(47-90)\end{array}$} & $<0.01$ \\
\hline & $\begin{array}{c}\text { After } \\
\text { circumcision }\end{array}$ & $\begin{array}{c}73.1 \pm 10.2 \\
(51-99)\end{array}$ & & & 0.77 \\
\hline \multirow{2}{*}{$\begin{array}{l}\text { BCS } \\
\text { (questions } \\
30-35-40 \text { ) }\end{array}$} & $\begin{array}{c}\text { Before } \\
\text { circumcision }\end{array}$ & $\begin{array}{c}8.6 \pm 2.2 \\
(3-12)\end{array}$ & \multirow{2}{*}{$<0.01$} & \multirow{2}{*}{$\begin{array}{c}4.5 \pm 1.3 \\
(3-7)\end{array}$} & $<0.01$ \\
\hline & $\begin{array}{c}\text { After } \\
\text { circumcision }\end{array}$ & $\begin{array}{c}4.4 \pm 0.9 \\
(3-6)\end{array}$ & & & 0.89 \\
\hline \multirow{2}{*}{$\begin{array}{l}\text { LSAS: } \\
\text { Anxiety }\end{array}$} & $\begin{array}{c}\text { Before } \\
\text { circumcision }\end{array}$ & $\begin{array}{c}38.5 \pm 8.1 \\
(25-59)\end{array}$ & \multirow{2}{*}{$<0.01$} & \multirow{2}{*}{$\begin{array}{c}32.8 \pm 5.8 \\
(24-44)\end{array}$} & $<0.01$ \\
\hline & $\begin{array}{c}\text { After } \\
\text { circumcision }\end{array}$ & $\begin{array}{c}30.8 \pm 6.1 \\
(24-45)\end{array}$ & & & 0.18 \\
\hline \multirow{2}{*}{$\begin{array}{l}\text { LSAS: } \\
\text { Anxiety } \\
\text { (questions } \\
4-24 \text { ) }\end{array}$} & $\begin{array}{c}\text { Before } \\
\text { circumcision }\end{array}$ & $\begin{array}{c}4.9 \pm 1.5 \\
(2-8)\end{array}$ & \multirow{2}{*}{$<0.01$} & \multirow{2}{*}{$\begin{array}{c}2.6 \pm 0.6 \\
(2-4)\end{array}$} & $<0.01$ \\
\hline & $\begin{array}{c}\text { After } \\
\text { circumcision }\end{array}$ & $\begin{array}{c}2.6 \pm 0.6 \\
(2-4)\end{array}$ & & & 0.65 \\
\hline \multirow{2}{*}{$\begin{array}{l}\text { LSAS: } \\
\text { Avoidance }\end{array}$} & $\begin{array}{c}\text { Before } \\
\text { circumcision }\end{array}$ & $\begin{array}{c}41.3 \pm 8.2 \\
(27-63)\end{array}$ & \multirow{2}{*}{$<0.01$} & \multirow{2}{*}{$\begin{array}{c}34.3 \pm 5.5 \\
(25-46)\end{array}$} & $<0.01$ \\
\hline & $\begin{array}{c}\text { After } \\
\text { circumcision }\end{array}$ & $\begin{array}{c}32.3 \pm 6.4 \\
(25-48)\end{array}$ & & & 0.17 \\
\hline \multirow{2}{*}{$\begin{array}{l}\text { LSAS: } \\
\text { Avoidance } \\
\text { (questions } \\
4-24 \text { ) }\end{array}$} & $\begin{array}{c}\text { Before } \\
\text { circumcision }\end{array}$ & $\begin{array}{l}5.2 \pm 1.4 \\
\quad(2-8)\end{array}$ & \multirow{2}{*}{$<0.01$} & \multirow{2}{*}{$\begin{array}{c}3.3 \pm 1.1 \\
(2-6)\end{array}$} & $<0.01$ \\
\hline & $\begin{array}{c}\text { After } \\
\text { circumcision }\end{array}$ & $\begin{array}{c}3.3 \pm 0.7 \\
(2-5)\end{array}$ & & & 0.45 \\
\hline \multirow{2}{*}{ IELT } & $\begin{array}{c}\text { Before } \\
\text { circumcision }\end{array}$ & $\begin{array}{c}77.7 \pm 52.7 \\
(0-180)\end{array}$ & \multirow{2}{*}{$<0.01$} & \multirow{2}{*}{$\begin{array}{c}79.8 \pm \\
56.5 \\
(0-240)\end{array}$} & 0.93 \\
\hline & $\begin{array}{c}\text { After } \\
\text { circumcision }\end{array}$ & $\begin{array}{c}85.4 \pm 47.7 \\
(0-180)\end{array}$ & & & 0.38 \\
\hline \multirow{2}{*}{ PEDT } & $\begin{array}{c}\text { Before } \\
\text { circumcision }\end{array}$ & $\begin{array}{c}9.3 \pm 5.8 \\
(0-20)\end{array}$ & \multirow{2}{*}{$<0.01$} & \multirow{2}{*}{$\begin{array}{c}8.6 \pm 4.4 \\
(1-20)\end{array}$} & 0.69 \\
\hline & $\begin{array}{c}\text { After } \\
\text { circumcision }\end{array}$ & $\begin{array}{c}7.9 \pm 5.2 \\
(0-20)\end{array}$ & & & 0.69 \\
\hline than & ELT: ir & D. & 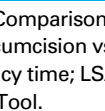 & & $\begin{array}{l}\text { efore } \\
\text { BCS: }\end{array}$ \\
\hline
\end{tabular}

\section{Discussion}

Several studies have been conducted on the effects of circumcision on erection, ejaculation, sexual disorders, and urogenital infections. ${ }^{14-18}$ Cuceloglu reported that circumcision affected PE. He showed that circumcision performed after seven years of age increased risk for future PE when compared to those having the procedure at an earlier age. ${ }^{19}$ Collins and Tian reported that adult circumcision did not have any effects on male sexual life in terms of erection, ejaculation, or overall satisfaction. ${ }^{14,20}$ Most of these studies were performed in patients circumcised in childhood. Our results showed that there were no significant differences between pre-and postoperative study group and control group. However comparisons of pre-circumcision and postcircumcision had significant difference for PEDT scores, IELT values, and presence of PE. In addition, evaluation of the items of sexuality in BCS and LSAS showed circumcision improved the sexual satisfaction in the study group.

Although some studies in the literature investigated the physical effects of adult circumcision, no recent study investigated its psychological effects. Further, studies have mostly focused on circumcision performed in childhood. One study showed that both medical and traditional circumcision increased the risk for anxiety disorder. However, traditional circumcision carried more risk for anxiety. ${ }^{21} \mathrm{~A}$ review by Yavuz et al hypothesized that circumcision might not affect children negatively due to: 1 ) the positive view attributed to circumcision in the community; 2) performing circumcision at an age when the child could appreciate circumcision and its consequences; and 3) most of the people in the community had been circumcised..$^{22}$ This is supported by the argument that advises to perform circumcision at an age when the child could make his own decisions, since the child perceives it as a threat.

Social anxiety disorder (SAD) is an anxiety disorder in which the individual continuously carries the fear that he/she will be embarrassed, humiliated, and considered ridiculous or clumsy in social situations and avoids them. ${ }^{23}$ Individuals with SAD have significantly worse body image and selfconfidence compared to healthy controls. ${ }^{24}$ Body image is a multidimensional concept involving perception, attitudes,

\begin{tabular}{|c|c|c|c|c|c|}
\hline & & $\begin{array}{c}\text { Study } \\
n=37\end{array}$ & $\begin{array}{c}p \\
\text { value }^{1}\end{array}$ & $\begin{array}{c}\text { Control } \\
n=30\end{array}$ & $\begin{array}{c}p \\
\text { value }\end{array}$ \\
\hline \multirow{2}{*}{$\begin{array}{l}\text { Premature } \\
\text { ejaculation }\end{array}$} & $\begin{array}{c}\text { Before } \\
\text { circumcision }\end{array}$ & $\begin{array}{l}\mathrm{No}=25 ; \\
\mathrm{Yes}=12\end{array}$ & \multirow{2}{*}{$<0.05$} & \multirow{2}{*}{$\begin{array}{l}\mathrm{No}=23 \\
\mathrm{Yes}=7\end{array}$} & 0.42 \\
\hline & $\begin{array}{c}\text { After } \\
\text { circumcision }\end{array}$ & $\begin{array}{l}\mathrm{No}=29 \\
\mathrm{Yes}=8\end{array}$ & & & 0.87 \\
\hline
\end{tabular}

${ }^{1}$ Analysis before and after circumcision (study group); ${ }^{2}$ Comparisons of (study group before circumcision vs. control group) \& (study group after circumcision vs. control group); IELT: intravaginal ejaculation latency time. 
thoughts, beliefs, feelings, and behaviour of the individual. It may be defined as the picture of one's own body in one's own mind. ${ }^{25,26}$ Individuals with a negative body image are known to avoid meeting with new people and being in social situations. This pattern of avoidance is common in $\mathrm{SAD}$ and body dysmorphic disorder. ${ }^{27,28}$

No studies in the literature have investigated the effect of adult circumcision on body image and social phobia. Our study is the first one. Our study showed significant improvements on body image and social anxiety levels after adult circumcision. Psychoanalytic views have hypothesized that preputium was considered as part of the penis and that its removal could cause perception of physical deficiency. ${ }^{29}$ The varying opinions may be related to different cultures and religions of the study population, as well as that of investigators. It was reported that the Turkish population did not accept absence of circumcision; boys felt ashamed of it and perceived their bodies as defective. A similar study performed on the Turkish population reported that circumcision created a social stress and children did not feel themselves as true males without circumcision. ${ }^{30,31}$ Apart from Muslims, it was reported that Jewish children also considered circumcision as blessed and culturally important and did not regard it as a punishment. ${ }^{2}$

Our results showed that circumcision improved physical and social perception not only in childhood, but also in adulthood. After circumcision, our patients change of answers to the question concerning public bathrooms in the social phobia scale indicates that they had the anxiety of lack of circumcision in adulthood and regarded it as a physical defect.

Significant improvements observed in the scores of items with a sexual content in BCS and LSAS indicated that circumcision had positive effects in terms of sexual life and confidence. As we evaluate these findings with PE effects, it seems that circumcision improves sexual satisfaction. Conflicting results among the studies for the effect of circumcision on sexual life may be explained by cultural differences.

As a limitation, we had relatively small sample size due to the fact that in Turkey, circumcision is most often performed in childhood.

\section{Conclusion}

As far as we know, no recent studies investigated both psychological and sexual effects of adult circumcision. Our results indicated psychosocial and physical negative effects in adult age when circumcision is not performed in childhood; however these negative effects can be improved after circumcision, even if it occurs in adulthood. Also, circumcision can improve sexual satisfaction. Being circumcised contributes to psychosocial and sexual well-being of individuals in adulthood.

Competing interests: The authors declare no competing financial or personal interests.

Acknowledgment: Ethical Approval was taken according to WMA declaration of Helsinki (Ethical Principles for Medical Research Involving Human Subjects) with the paper number of "07. Nov.2014.8000-45-14/KAL.GUV."

This paper has been peer-reviewed.

\section{References}

1. Remondino P. History of Circumcision from the earliest times to the present. Honolulu, Hawaii: University Press of the Pacific; 2001.

2. Dekkers W, Hoffer C, Wils JP. Bodily integrity and male and female circumcision. Med Health Care Philos 2005;8:179-91. http://dx.doi.org/10.1007/s1 1019-004-3530-z

3. Dunsmuir WD, Gordon EM. The history of circumcision. BJU Int 1999;83:1-12. http://dx.doi. org/10.1046/i.1464-410x.1999.0830s1001.x

4. Introcaso CE, XU F, Kilmarx PH, et al. Prevalence of circumcision among men and boys aged 14 to 59 years in the U.S., National Health and Nutrition Examination Surveys 2005-2010. Sex Transm Dis 2013;40:521-5. http://dx.doi.org/10.1097/01.0LQ.0000430797.56499.0d

5. WHO. Male circumcision: Global trends and determinants of prevalence, safety and acceptability. 2007; http://apps.who.int/iris/bitstream/10665/43749/1/9789241596169_eng.pdf. Accessed April 4, 2016.

6. Homfray V, Tanton C, Mitchell KR, et al. Examining the association between male circumcision and sexual function: Evidence from a British probability survey. AIDS2015;29:1411-6. http://dx.doi.org/10.1097/ QAD. 0000000000000745

7. Nunberg H. Circumcision and the problems of bisexuality. Rev Psicoanal 1952;9:55-122.

8. McMahon CG, Althof S, Waldinger MD, et al. An evidence-based definition of lifelong premature ejaculation: Report of the International Society for Sexual Medicine Ad Hoc Committee for the Definition of Premature Ejaculation. BJU Int 2008;102:338-50. http://dx.doi.org/10.1111/i.1464-410X.2008.07755.x

9. Secord PF, Jourard SM. The appraisal of body-cathexis: Body-cathexis and the self. J Consult Psychol 1953;17:343-7. http://dx.doi.org/10.1037/h0060689

10. Selim H. The study of reliability and validity of body cathexis scale: Bachelor's degree thesis (unpublished) Ankara: Gazi University 1990.

11. Soykan C, Ozguven HD, Gencoz T. Liebowitz Social Anxiety Scale: The Turkish version. Psychol Rep 2003;93:1059-69. http://dx.doi.org/10.2466/PR0.93.8.1059-1069

12. Symonds $T$, Perelman $M A$, Althof $S$, et al. Development and validation of a premature ejaculation diagnostic tool. Eur Urol 2007;52:565-73. http://dx.doi.org/10.1016/i.eururo.2007.01.028

13. Serefoglu $\mathrm{EC}$, Cimen HI, Ozdemir AT, et al. Turkish validation of the premature ejaculation diagnostic tool and its association with intravaginal ejaculatory latency time. Int I Impot Res 2009;21:139-44. hittp:// dx.doi.org/10.1038/iiir.2008.58

14. Collins $S$, Upshaw J, Rutchik $S$, et al. Effects of circumcision on male sexual function: Debunking a myth? J Urol 2002;167:2111-2. http://dx.doi.org/10.1016/S0022-5347(05)65097-5

15. Shen $Z$, Chen $S$, Z Zhu $C$, et al. Erectile function evaluation after adult circumcision. Zhonghua Nan $K e$ Xue 2004;10:18-9.

16. Yang MH, Tsao CW, Wu ST, et al. The effect of circumcision on young adult sexual function. Kaohsiung J Med Sci 2014;30:305-9. http://dx.doi.org/10.1016/i.kims.2013.10.004

17. Zhang SJ, Zhao YM, Zheng SG, et al. Correlation between premature ejaculation and redundant prepuce. Zhonghua Nan Ke Xue 2006;12:225-7.

18. Houle AM. Circumcision for all: The pro side. Can Urol Assoc J 2007;1:398-400.

19. Cuceloglu EA, Hosrik ME, Ak M, et al. The effects of age at circumcision on premature ejaculation. Turk Psikiyatri Derg 2012;23:99-107. http://dx.doi.org/10.5080/u6601

20. Tian Y, Liu W, Wang JZ, et al. Effects of circumcision on male sexual functions: A systematic review and meta-analysis. Asian J Androl 2013;15:662-6. http://dx.doi.org/10.1038/aja.2013.47 
Aydogmus et al.

21. Watson CG, Juba MP, Manifold V, et al. The PTSD interview: Rationale, description, reliability, and concurrent validity of a DSM-III-based technique. J Clin Psychol 1991;47:179-88. http://dx.doi. org/10.1002/1097-4679(199103)47:2<179::AID-JCLP2270470202>3.0.C0;2-P

22. Yavuz $M$, Demir T, Dogangun $B$. The effect of circumcision on the mental health of children: $A$ review. Turk Psikiyatri Derg 2012;23:63-70.

23. Kerns CE, Comer JS, Pincus DB, et al. Evaluation of the proposed social anxiety disorder specifier change for DSM-5 in a treatment-seeking sample of anxious youth. Depress Anxiety 2013;30:709-15. http:// dx.doi.org/10.1002/da.22067

24. Izgic $F$, Akyuz $G$, Dogan 0 , et al. Social phobia among university students and its relation to self-esteem and body image. Can J Psychiatry 2004;49:630-4.

25. Cash TF. Body image: Past, present, and future. Body Image 2004;1:1-5. http://dx.doi.org/10.1016/ S1740-1445(03)00011-1

26. Cohen A. Body image in the person with a stoma. J Enterostomal Ther 1991;18:68-71.
27. Doğan T, Sapmaz F, Totan T. Adaptation of the body image coping strategies inventory to Turkish: A validity and reliability study. Anadolu Psikiyatri Derg 2011;12:121-9.

28. Levinson CA, Rodebaugh TL, White EK, et al. Social appearance anxiety, perfectionism, and fear of negative evaluation: Distinct or shared risk factors for social anxiety and eating disorders? Appetite 2013;67:12533. http://dx.doi.org/10.1016/i.appet.2013.04.002

29. Gollaher DL. Circumcision: A history of the world's most controversial surgery: Basic Books; 2001.

30. Ozturk OM. Ritual circumcision and castration anxiety. Psychiatry 1973;36:49-60.

31. Sahin F, Beyazova U, Akturk A. Attitudes and practices regarding circumcision in Turkey. Child Care Health Dev 2003;29:275-80. http://dx.doi.org/10.1046/i.1365-2214.2003.00342.x

Correspondence: Dr. Yasin Aydogmus, Etimesgut Military Hospital, Ankara, Turkey; yasinaydogmus@gmail.com 